\title{
The Issue of Understanding Muslim Culture*
}

\author{
Nur Kirabaev \\ Department of History of Philosophy \\ Faculty of Humanities and Social Sciences \\ Peoples' Friendship University of Russia \\ 6 Miklukho-Maklaya Street \\ Moscow, Russia 117198 \\ E-mail:kirabaev@gmail.com
}

\author{
Maythem Al-Janabi \\ Department of History of Philosophy \\ Faculty of Humanities and Social Sciences \\ Peoples' Friendship University of Russia \\ 6 Miklukho-Maklaya Street \\ Moscow, Russia 117198 \\ E-mail: m-aljanabi@mail.ru
}

\begin{abstract}
The authors of the article consider the culture of Islam in the context of the two contradictory tendencies of contemporaneity: globalization and localization. Rather, globalization may be perceived as an ideal construction with the optimistic myth of progress embedded in it. At the same time, it represents empirical and ideological uncertainty which indicates the insufficiency of our knowledge and, accordingly, the understanding of the contemporary globalizing space. The coexistence and interpretation between globalization and localization, as well as the strengthening of the role of traditions, force us to go beyond mentality in the either-or dichotomy because today there is an increasing contradiction between globalization as a theory of modernization and globalization as an empirical process. Globalization has called into question the preservation and development of cultural and civilizational diversity. The authors consider it important to answer and address following issue: what do we know about Islam, Muslim civilization and Muslim cultures in the context of globalization and localization processes? The authors outline and put into context the issue from the point of view of the problem of understanding the Muslim civilization.
\end{abstract}

Keywords-globalization; localization; stereotypes and autostereotypes; Eurocentrism; Muslim civilization and culture; Islam; civilizational solidarity; knowledge centrism; Adab; Adib; Humanism; esoteric and exoteric knowledge

\section{INTRODUCTION}

Despite the prophetic predictions of F. Fukuyama [1] and S. Huntington [2], the tragedy of $9 / 11$ and the subsequent military conflicts across the Middle East, terrorist attacks in a number of countries in Europe, Asia, and Russia as well, the "History with the capital $\mathrm{H}$ " has not ended and civilizations have not clashed. It is obvious that due to the diversity of local civilizations, the historical process cannot be reduced to and be understood as just a linear progressive development. It should be noted that contemporaneity is developing within the framework of two contradictory trends: globalization and localization. Globalization may be viewed as some ideal construction with an optimistic myth of progress embedded in it and globalization as discourse is ideological rhetoric on the one hand and an empirical process on the other. It is the latter that allows talking about discursive plurality and the

*Fund: The article has been prepared with the support of RUDN grant №100336-0-000 "Philosophy and Culture: Stereotypes and Autostereotypes" plurality of practices of local civilizations. We may state that representing both empirical and ideological uncertainty, globalization speaks about the insufficiency of our knowledge and, accordingly, the understanding of what the globalized space of our time is. Increasing ideological rhetoric on globalization often leads to its mystification as an empirical process. It is important to bear in mind that globalization is described as both a final process and a wholeness. Indeed, globalization as an irreversible process creates a single space through education, research and technology, migration, media, finance, tourism, and trade which are developing at an unprecedented rate. At the same time, the prevalence and depth of local identity are defined in terms of language, territory, ethnicity, religion, and tradition - this being a real image of our time. Of course, market, democracy, civil society, and human rights as traits of the modernization of society, have taken on a global significance, yet, at the same time, the power of tradition in contemporaneity is playing an increasing role.

Co-existence and convergence between globalization and localization, and the strengthening role of tradition, the quest for new models of identity force us to go beyond the mentality in the either-or dichotomy, because today is obvious the growing contradiction between globalization as the theory of modernization and globalization as an empirical process that allows us to speak about "multilinearity of world-historic process" [3]. It should be noted that at least three optimistic postulates of globalization as an ideal construction have proved untenable: the reduction of the role of nation states; the openness of borders for the unhindered movement of goods, capital, and people; the establishment of homogenous liberal world order. Worth noting that the multiplicity of globalization practices has given rise to various consequences, including, as a response - the increasing role of the religious factor in world politics and economy, as well as the focus on the search for identity. This circumstance has led to an increasing role and practice of the so-called religious fundamentalism and extremism. The example of the so-called Islamic State (ISIS), banned in many countries, is a piece of clear evidence. At the same time, it was at the level of ideological rhetoric under the domination of the Western mediacracy in shaping public opinion towards demonizing Muslim civilization through Islam and Muslim culture. 


\section{CULTURAL INTERACTION AND EUROCENTRISM}

Cultural interaction as Us-Them and comprehension of some cultures in concepts and terms of the others, on the one hand, form and develop so-called stereotypes, i.e. clichés as images of perception of other cultures, on the other hand, beget autostereotypes - clichés as images of an individual's own culture. It is within the framework of the interaction of cultures that the development and a kind of correction of stereotypes and autostereotypes, largely dependent on the specific historical context of the perception of our and their cultures, take place. The comparative analysis of various ways of perception of other cultures, included or not in the framework of one's own culture, allows raising further questions of intercultural communication, ethnocultural identity, and cultural self-identity. The study of this issue is often complicated by the socio-cultural practice of Eurocentrism, which reflects the theoretical reflection of the consideration of other cultures as "barbaric" which has been common since the days of ancient Rome. In many studies on Eurocentrism, researchers bring into the spotlight the interrelation of the historical process of transition of natural and state (national) ethnocentrism to Eurocentrism that is a kind of regionalism wishing to carry out its global expansion [4]. The roots of natural ethnocentrism, from which racism later grows, are in the times of ancient Rome, when the Us vs. Them division was brought to life and developed, e.g. in an attitude towards the barbaric culture, opposing the Roman culture perceived as a paragon. Political and economic consequences of the Age of Discovery are generally associated with the amplification of Eurocentrism ensuring colonialism and expansionism, from military and economic to political and cultural. Thus, we may say that Eurocentrism is based on historically formed traditional ethnic, racial, religious, and nationalist stereotypes, which are reflected in various philosophical theories. The renowned Russian historian of philosophy A.V. Sagadeyev noted: "As traditional are considered the views based primarily on the territorial-geographic distinction of $U s$ and Them, and on the largest socio-cultural communities to which they belong East and West" [5]. After the release of Edward Said's Orientalism, dedicated to the Western concepts of the East, the issue of Eurocentrism, being the dominant methodological and theoretical concept, once again became the subject of wide discussion and debate [6]. "Said demonstrated very clearly and convincingly that the knowledge of the East (whether academic, artistic, visual, etc.), being formed in European countries through the last centuries, has never been neutral in relation to the practice of conquest and suppression, which Europe carried out towards "non-European" (primarily Eastern) cultures and territories" [7].

\section{TRAITS OF MUSLIM CIVILIZATION AND CULTURE}

In the history of humanity, the civilization of the Muslim East has played a significant role and continues to impact various areas of life in different countries around the world. In an increasingly globalizing world, the Islamic factor, in general, requires a philosophical comprehension of the cultural traditions of the peoples of the Muslim East in the context of the problems of traditionalism, modernization, and the search for a contemporary idea of identity. Muslim civilization isn't directly linked to any geographical location but encompasses the entire continental and subcontinental world. Thus, the peoples and countries that count themselves to Muslim civilization, that identify themselves as a part of the Muslim world, are consolidated precisely by the peculiarity of what is called the concept of Islam and Muslim civilization. Muslim civilization unites people belonging to different ethnicities, cultures, languages, and traditions, from Syria to Malaysia, from Tatarstan to South Africa. At the same time, it's difficult to talk about a single historical community of the destinies of these peoples. Islam shall be considered as unity in diversity. We should consider a special kind of solidarity-based not only on faith in Allah but also on a shared attitude and vision. However, this civilizational solidarity is not monolithic and conflict-free, it doesn't exist in a pure form, but it is the result of crosscultural interaction in the broad sense of the concept. Its peculiarity is its contingence to religion which is a way of life, a system of values, the socio-political and economic institutions. Islam may be viewed as one of the most viable world religions, dynamically adapting to the peculiarities of the traditions of peoples. The increase in the number of Muslims in the contemporary world is largely linked to the attraction of new adherents, "fascinated" by the simplicity and attractiveness of Islam.

Understanding the paradigm of Muslim civilization and comprehension of its historical role are associated not only with the identification but also with the nature of sociocultural interlinking with other civilizations as their universal dimension. At the heart of this spiritual paradigm is the diversity of cultural and ideological phenomena, especially in the historical period during which the paradigm has received a relatively complete and stable form. Comprehension of this paradigm assumes historical and philosophical consideration of cultural phenomena and ideological images of that era.

The values of Muslim culture, as, indeed, any other culture, are largely determined by the so-called basic values that form the foundation of value consciousness in its integrity. The basic values of Muslim culture were largely determined by the peculiarities of the advent and development of Islam as well as of the development of the Abbasid Caliphate and the Umayyad dynasty.

The distinctive features of classical Muslim culture as a paradigm of Muslim culture as a whole are largely determined by the fact that it was formed as an integral part of a holistic Mediterranean culture and civilization, and by the fact that Muslim culture has preserved and multiplied the cultural, scientific, and philosophical traditions of the ancient world, and nurtured as well the humanistic character of Mediterranean culture but under different socio-economic and historical conditions. The hosts and creators of ArabMuslim culture as a phenomenon of cross-cultural interaction, were the Arabs, the Turks, the Persians and other peoples united by Islam and the Arabic language. Famously, the honorary title of the First Teacher in Arab-Muslim culture and philosophy is attributed to Aristotle, Plato's 
authority is also high, and the ancient heritage is considered as the source and integral part of the Muslim culture. Between the $9^{\text {th }}$ and the $13^{\text {th }}$ centuries, Arab-Muslim culture flourished in vast areas from Indus to the Iberian Peninsula, from Transoxiana to North Africa.

\section{ARAB AND Muslim Culture: KNOWLEDGE CENTRISM}

The development of Muslim civilization was closely associated with the birth and strengthening of Islam and the Caliphate, the vast space of which became a new center of interaction and mutual enrichment of various cultural and religious traditions. The Islamic Golden Age dated from the $9^{\text {th }}$ to the $13^{\text {th }}$ century. One of the major traits of classical Muslim culture is that its main structural element is not science, as it was in the history of the Western European thought, but Islamic religious and ideological schools, defining and determining the nature of knowledge and the scope of acceptable understanding and interpretation of the world. These schools share a common paradigm that is based on a certain set of assessments and representations relating to the ultimate foundations of human existence in the world, his nature and connection with space, reflected by the Islamic Weltanschauung. The thinkers of the Muslim Middle Ages were dealing with each problem individually in this field of knowledge - including the problems of culture, politics, ethics, aesthetics, philosophy, and law. All the major philosophical and socio-political schools of the Muslim Middle Ages were not limiting themselves to only one specific field of knowledge - they acted as political schools in relation to political issues, as philosophical ones - to philosophical issues, as legal ones - to legal issues, as ethical ones - to moral issues, etc.

The peculiarities of the ideal of knowledge in Muslim culture were determined by Sharia, according to which, faith and reason do not oppose but complement each other in the given field of knowledge. Thus, medieval Muslim culture proceeded and was guided by such an ideal of knowledge, which, by its nature, was interdisciplinary. For instance, the work of the famous medieval thinker al-Ghazali (1058 1111) The Revival of the Religious Sciences (Ihyā' 'Ulūm alDīn) can be considered as philosophical, legal, religious, linguistic, and cultural at the same time - i.e., interdisciplinary in the modern sense [8].

The American orientalist Franz Rosenthal emphasizes in his Knowledge Triumphant: The Concept of Knowledge in Medieval Islam [9] that in Arab-Muslim civilization knowledge has acquired a significance, unmatched in other civilizations. Knowledge in question is both secular and religious; however, its constitutive place in the value system of medieval Muslim society indicates, at least, that the authority of educated people was far-reaching. Since Islam lacks the ordination institution, even the authority and status of religious leaders depended on their education. The character of the Muslim society's value orientation is evident through the so-called adab literature. We're talking about $u d a b a$, who embodied the image of cultured and educated people. Adab, a set of norms of education and upbringing, assumed knowledge of both secular and religious sciences, in particular, philosophy, astronomy, mathematics, and a certain model of behavior. Thus, we may argue that the Arab-Muslim culture was knowledge-centric.

\section{PECUliarities of Islamic CUlture AND HUMANISM}

Such features of Islam as the absence of the institution of the church and, consequently, the institution of ordaining and dogmatic church ideology are of great importance for understanding the paradigm of Muslim culture. The absence of a mediator between God and an individual has led to the attribution of a law-making role solely to God and, accordingly, this also explains the absence of orthodoxy and heresy in the Christian meaning. Moreover, the practice of Islamic development was based on religious and legal pluralism within the shared Islamic worldview. A researcher, describing the paradigm of Muslim culture and civilization should distinguish at least two dominant components: Islam and Hellenism. Throughout its history, this culture has shown and still shows both its "Western" face - as it contains the elements of Judaism, Christianity and Hellenism - and its "Eastern" face - when it departs from the essence of these components. Taking the latter into account makes it possible to comprehend the humanistic nature of Muslim culture, associated with the attempt to make an individual more humane and to contribute to the disclosure of his greatness. There are three aspects of humanism in Muslim culture:

- religious humanism, which proclaims a human the pinnacle of God's creation;

- adabic humanism, the ideal of which is an Adab, formed in the 9th century, corresponds to the 16thcentury European ideal of Humanitas, i.e. the ideal of developing the physical, moral, and intellectual abilities of a person in the name of the common good;

- philosophical humanism, more conceptualized, the essence of which Abu Hayyan al-Tawhidi (923 1023) summarized in the words: "Man has become a problem for man".

While paying tribute to and acknowledging the existence of universal traits and principles of humanism, we may at the same time argue that every culture and civilization, experiencing its heyday, develops its model of humanism. We should also consider that humanism assumes different shapes even within Muslim culture [10]. In the East this phenomenon first became apparent during the reign of Khosrow I and was represented by Barzu, Paul the Persian, and Salman the Persian. This is followed by humanism, influenced by Hellenistic Gnosticism, Hermeticism, and Neo-Platonism; a humane quest centered around the concept of the "perfect human" and presented by Ibn Arabi (11651240), Abdul Karim al-Jili (1077 - 1166), Mansur al-Hallaj (858 - 922) and Shahab al-Din Yahya ibn Habash Suhrawardi (1155 - 1191). Finally, humanism, which emphasize the greatness of the human mind (as in the Ahadith where the Prophet Muhammad is credited with the words: "Everyone who knows God knows himself"; "The first thing created by God is reason") is found in the works of 
Muhammad ibn Zakariya al-Razi (854 - 925), who rejected Revelation and affirmed the autonomy of the human mind in the spirit of European Enlightenment.

\section{ESOTERIC TO EXOTERIC CORRELATION}

Speaking of the esoteric to the exoteric ratio in the context of the problem, of reason and faith, it is necessary to note the nature of their complementarity. The analysis of the theological and philosophical level of the solution of the problem of the correlation of reason and the establishments of faith shows that, despite the differences in the standpoints of various thinkers, they are united by the fact that in general, they followed the esoteric tradition associated with the priority of mind. Thus, they have prepared the ground for Sufi esoteric knowledge and its intellectual attempt to harmonize Sharia and Tariqa as a justification for their approach to the problem. Sufism didn't consider the correlation of mind and faith as the "essence of the problem" but included it in a broader system of correlation of the Spiritual Stations (Sharia - Tariqa - Haqiqa). It should be noted that the Sharia - Tariqa - Haqiqa system builds a "logical form" of action of the cognizing subject in search of his Absolute, thus contributing to the emergence of many versions, one of which is the teaching of al-Ghazali. Realizing that Sufism is a historical and holistic phenomenon, we believe, it is important to study it, considering the archetypes of Sufi culture.

Philosophical analysis of Muslim culture requires the identification of the sustainable and changing elements in its paradigm throughout history. This should be considered while analyzing the concepts dealing with the so-called reformation or modernization of Islam. As a rule, the attempts made so far to create Western models of Islamic development have failed precisely because the traditional foundations that make up the spirit of Muslim culture have been accepted as something that can historically be overcome.

Meanwhile, socio-historical and political realities necessarily show that comprehending the essence of traditionality and modernity is closely related to the foundations of the Islamic political and legal culture and the dominant ideological and cultural movements within the framework of developing Islam. The analysis of the classical theories of the state in Islamic political thought presented by such authors as Al-Mawardi, Al-Juwayni, and Al-Ghazali, clearly shows that the Sharia principles didn't actually interfere with the consideration of the historical realities of the Caliphate and relied more on historical precedents. An invariable component of these concepts is the doctrine that the state is only a conductor of the Sharia principles. But the question is - who holds the real political power, how to perceive power and authority, what is the consolidating component and moral and spiritual basis of civil Muslim society. The idea of the unity of religion and state is based not only on a sense of religious solidarity but also on the need to understand that Islam is expected to establish equality and justice in socio-political and economic relations. Recognizing the fact that Islam is a way of life and a certain type of contemporary Weltanschauung makes it possible to understand the idea of a Muslim state in its very essence.

\section{CONCLUSION}

The distinctive features of Muslim culture and civilization should be considered not in the context of opposing East and West, old and new, past and present, identity and contemporaneity, traditionalism and rationalism, heritage and modernization, religion and nation, but in the context of these interrelationships. Considering this provision, it is important to note that in the philosophical and value dimension, the classical Arab-Muslim culture was open to interaction with other cultures since its formation and development was the result of cross-cultural interaction and it was indeed a border culture. As for the present-day Islamic culture, if it is not opposing, it isn't ready, open, for an inter-civilizational dialogue. One of the main problems in the area of Muslim culture at present is the determination of what should remain unchanged in addressing the issue of Islam as a civilizational phenomenon and nationalism as a national and state dimension in the context of the transition to industrial and post-industrial development of Muslim Oriental societies.

\section{REFERENCES}

[1] F.Fukuyama.The End of History and the Last Man. Free Press, 1992

[2] S. Huntington. The Clash of Civilizations and Remaking the World Order. Simon \& Schuster, New York, 1996, 368 P.

[3] Eurasian Idea and Contemporaneity. Edited by N.S. Kirabaev. M.: RUDN, 2002, p. 94.

[4] Shubina M.M. Establishment of Eurocentrism and Racial Theories in the Context of Classical Philosophical Anthropology. Shahty: GOU VPO "YURGES", 2008.

[5] Sagadeyev, A.V. Stereotypes and Autostereotypes in Comparative Studies of Eastern and Western philosophy // Philosophical Heritage of the Peoples of the East and Contemporaneity. M.: Nauka, Chief Redaction of Oriental Literature, 1983, p. 1.

[6] E. W. Said. Orientalism. 3rd ed. N.Y., 2003.

[7] Orientalism vs. Orientalistics: Collected Articles / Composed and edited by Bobrovnikov, V.O., Miri, S.J. M.: Sadra, 2016, p. 8.

[8] al-Ghazali. The Revival of the Religious Sciences (Ihyā' 'Ulūm alDīn). Cairo, without year. Vol. 1-4.

[9] Rosenthal F. Knowledge Triumphant: The Concept of Knowledge in Medieval Islam. M.: Nauka, 1978, p. 324.

[10] Sagadeyev, A.V. Humanistic Ideals of the Islamic Middle Ages / A. Sagadeyev // Values in Islamic Culture and the Experience of History. Russian Philosophical Studies, I. Ed. by N. Kirabaev, Y. Pochta. Washington, 2002, pp. 165-198 